\title{
The Roosevelt-Rondon expedition marmoset Mico marcai: unveiling the conservation status of a Data Deficient species
}

\author{
Felipe Ennes Silva, Hani Rocha El Bizri, Jonas da Rosa Gonçalves \\ Lísley P. Lemos, Rodrigo Costa-Araúo, Ivan J. Lima \\ Aline Tavares Santos, Marcelo Ismar Santana \\ Caetano L. B. Franco and Jean P. Boubli
}

\begin{abstract}
The Roosevelt-Rondon Expedition marmoset Mico marcai was first collected in 1914 and all information on this primate previously came from three skins brought back by this expedition. As a result, M. marcai is categorized as Data Deficient on the IUCN Red List. As the presumed range of $M$. marcai lies on the path of the advancing arc of deforestation in Brazil, the collection of relevant data to assess the conservation status of this Amazonian species is of some urgency. Here we present the first field data on the distribution and population size of, and threats to, M. marcai, to reassess the species' conservation status. During 2012-2015 we surveyed the species in the MarmelosAripuanã interfluve, and estimated its density using distance sampling. We also used spatial predictive modelling to estimate forest loss within the species range under two deforestation scenarios. We found the marmoset in 13 localities and estimated its extent of occurrence to be $31,073 \mathrm{~km}^{2}$. We estimated the species' density to be 8.31 individuals/ $\mathrm{km}^{2}$ and extrapolated this to estimate a total population of 258,218 individuals (CI 150,705-441,860). Under a businessas-usual deforestation scenario, c. $10,000 \mathrm{~km}^{2}$ of forest, comprising $33 \%$ of the species' range, would be lost in three marmoset generations (c. 18 years), and we, therefore, recommend that M. marcai be categorized as Vulnerable
\end{abstract}

Felipe EnNes Silva* (Corresponding author) and Jean P. Boublił School of Environment and Life Sciences, University of Salford, M5 4WT, Salford, UK E-mail interfaceh@gmail.com (D) http://orcid.org/0000-0002-1315-0847

Hani Rocha El Bizrit, Jonas da Rosa Gonçalvest, J. Lima, Aline Tavares Santos $\dagger, \ddagger$ and Caetano L. B. Franco Instituto de Desenvolvimento Sustentável Mamirauá, Tefé, Brazil

Rodrigo Costa-Araújo Laboratorio de Evolução e Genética Animal, Universidade Federal do Amazonas, Manaus, Amazonas, Brazil (D) http://orcid.org/0000-0002-6092-4892

Marcelo Ismar Santana Faculdade de Agronomia e Medicina Veterinária, Universidade de Brasília, Campus Universitário Darcy Ribeiro, Brasília, Distrito Federal, Brazil

*Also at: Instituto de Desenvolvimento Sustentável Mamirauá, Tefé, Brazil $\dagger$ Also at: School of Science and the Environment, Manchester Metropolitan University, Manchester, UK, and Comunidad de Manejo de Fauna Silvestre en la Amazonía y en Latinoamérica, Iquitos, Peru

‡Also at: Instituto Nacional de Pesquisas da Amazônia, Manaus, Amazonas, Brazil

Received 23 November 2017. Revision requested 5 January 2018.

Accepted 8 February 2018. First published online 23 November 2018. on the IUCN Red List based on criterion $\mathrm{A}_{3} \mathrm{c}$. Other Amazonian marmosets require similar reassessment as their ranges also fall in the path of the arc of deforestation.

Keywords Brazil, conservation status, Data Deficient, forest loss, marmoset, Mico marcai, Roosevelt-Rondon Expedition, southern Amazonia

Supplementary material for this article is available at https://doi.org/10.1017/So030605318000303

\section{Introduction}

'The assessment of a species' extinction risk is the first 1 step towards its conservation. Species for which ecological and population data are lacking are categorized on the IUCN Red List as Data Deficient (IUCN, 2012), but it is preferable that such species are assessed fully as they could potentially be threatened. One such species is Marca's marmoset Mico marcai, endemic to southern Amazonia, an area heavily impacted by the advancing Brazilian agricultural frontier. In the Brazilian National Threat Assessment of Primates (ICMBio, 2018) M. marcai was the only marmoset categorized as Data Deficient, and it has the same categorization on the IUCN Red List (Rylands \& Silva Jr, 2008). This primate was first observed and collected by the Roosevelt-Rondon Expedition in 1914 but remained overlooked in the National Museum of Rio de Janeiro mammal collection for 79 years until Alperin (1993), in a revision of all marmosets of the argentata group, described it as a new taxon, Callithrix argentata marcai. This taxon was later elevated to full species and included in the genus Mico (Rylands et al., 200o).

The museum tag of the type specimen of M. marcai indicates it was collected at the confluence of the Roosevelt and Aripuanã Rivers (Alperin, 2002; Fig. 1). In 2000 van Roosmalen et al. (2000) described a new species of marmoset, $M$. manicorensis; its type locality is the confluence of the Manicoré and Madeira Rivers (Fig. 1). However, the hypothesized distribution of M. manicorensis encompasses the Manicoré-Aripuanã interfluve, including the type locality of M. marcai. Based on examination of the few available specimens, Garbino (2014) proposed that the van Roosmalen 


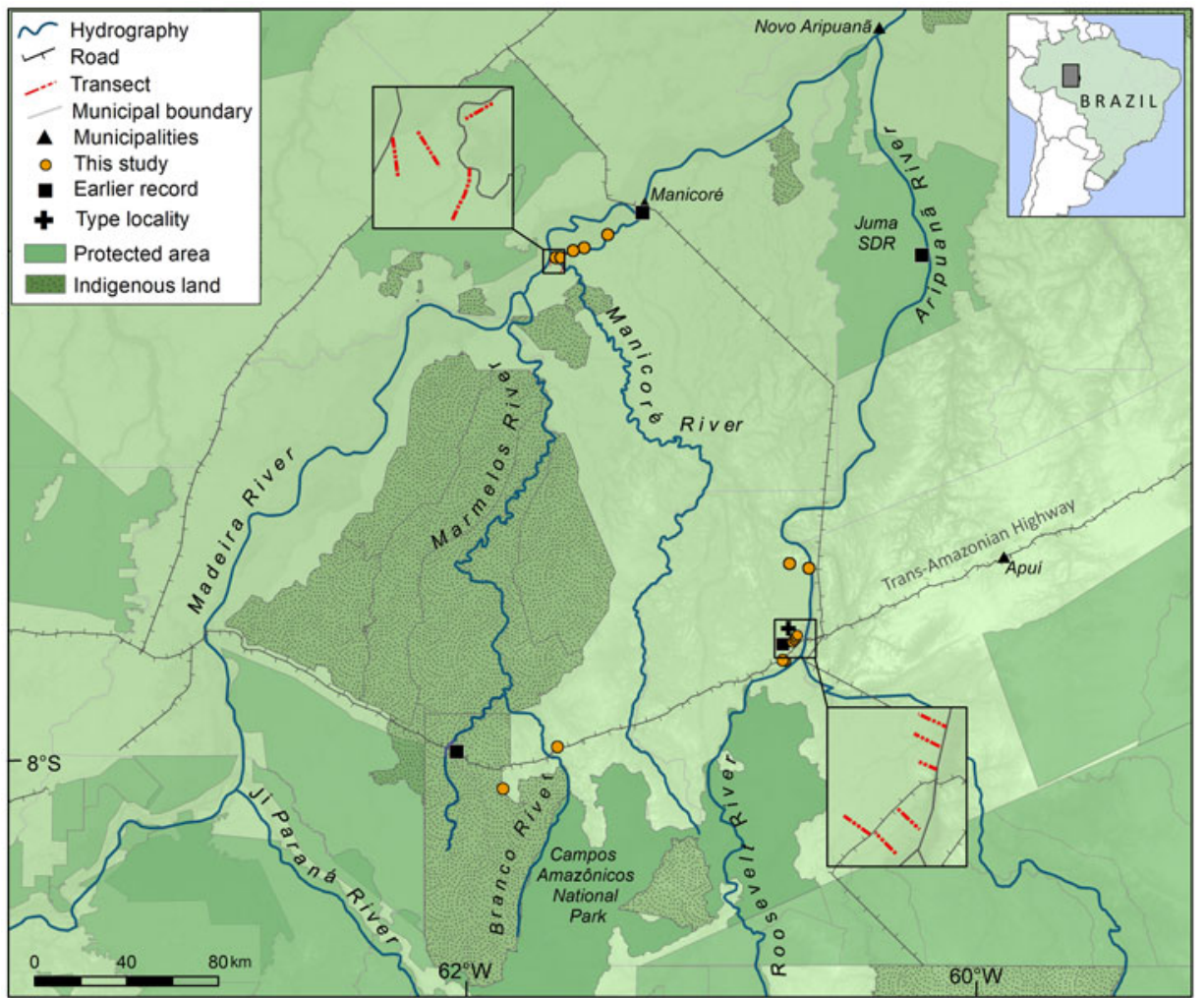

FIG. 1 Locations of the 10 transects used to survey for Mico marcai during January-February 2015, sightings from 2012-2014, earlier records from other observers (van Roosmalen et al., 200o; Rohe, 2007; Garbino, 2014) and the type locality (Alperin, 2002), in the AripuanãMarmelos interfluve of the Brazilian Amazon. Juma SDR, Açaí Grande Juma Development Reserve. et al. (2000) manicorensis was a junior synonym of marcai. Silva et al. (2013) presented the first information on the species occurrence in the wild, near its type locality, and discussed potential threats to the species.

Here we present the first investigation of the distribution and potential population size of M. marcai, using both field surveys and existing records, and assess the species' conservation status. In addition, using spatial predictive modelling, we predict the potential effect of two alternative land-use scenarios on the species' habitat. We believe this is the first study to categorize the conservation status of a Data Deficient Amazonian primate using uring a combination of field surveys and remote sensing data.

\section{Study area}

This study was carried out in the Marmelos-Aripuanã interfluve, two right bank tributaries of the Madeira River in Brazil (Fig. 1). The climate is tropical, with a short dry season in July-September, a mean annual temperature of $28^{\circ} \mathrm{C}$ and a mean annual precipitation of 2,500-3,000 mm/year (Hayakawa \& Rossetti, 2015). The vegetation comprises mostly upland forest, and seasonally flooded forests (open and dense lowland rainforest), and patches of pioneer and savannah-like vegetation (Supplementary Fig. 1; Anderson, 1981). This region lies within the arc of deforestation region of Amazonia, which is under severe threat from the rapidly expanding Brazilian agricultural frontier, urban encroachment, logging and infrastructure projects (Nepstad et al., 2001; Vieira et al., 2008). The study area lies in the municipality of Manicoré that, with Apuí municipality, is the main area for livestock production in Amazonas State, forming the arc of cattle ranching (Carrero et al., 2015). The area is considered a deforestation hotspot because of the presence of the federal road BR-230, also known as the Trans-Amazonian Highway (Fearnside et al., 2009; Carrero \& Fearnside, 2011).

\section{Methods}

\section{Surveys}

During 2012-2014 we carried out six expeditions to the Marmelos-Aripuanã interfluve to survey for marmosets and other primates, totalling 63 days of fieldwork. Our surveys included the confluence of the Roosevelt and Aripuanã rivers, the upper and lower Manicoré River, and the mid Aripuanã River (Fig. 1). Surveys were conducted using existing trails and roads, and with small boats. We recorded the location of all sightings, with a GPS, and, using these locality records and data from the literature (Ferrari, 1993; van Roosmalen et al., 2000; Alperin, 2002; Röhe, 2007; Garbino, 2014), we defined the species' extent of occurrence (EOO, sensu IUCN, 2012). We followed the IUCN (2012) guidelines to calculate the EOO as the minimum convex polygon that contains all of the species' records (IUCN, 2012). Assuming 
rivers are effective barriers to primate dispersal (Ayres \& Clutton-Brock, 1992), we adjusted this EOO accordingly to measure the total area potentially occupied by the species (i.e. its geographical range).

To estimate the species' density and abundance we surveyed two sites during January-February 2015. Survey transects were near the species' type locality and along the lower Manicoré River. In total, we opened six transects in the former site and four in the latter, averaging $3.07 \pm$ SD $0.63 \mathrm{~km}$ in length (Fig. 1). The positioning of transects was by randomization, using ArcGIS 10.2.2 (ESRI, Redlands, USA), of each trail starting point and direction from the main access points (roads or rivers). Nine transects were opened perpendicularly to these access points so that any gradient of environment and primate density from the start of the trail to the interior of the forest was accounted for. Transects were at least $2 \mathrm{~km}$ apart to avoid spatial dependence. We followed standardized field protocols for data collection, using distance sampling (Buckland et al., 1993) to estimate marmoset densities. Two observers walked transects at a mean speed of $1.5 \mathrm{~km} / \mathrm{h}$, recording the number of individuals sighted and the perpendicular distance from the transect to the centre of the group. Transects were surveyed during 7.00-11.00 in one direction and 14.00-17.00 in the reverse direction. Each transect was surveyed at least three times, with a 2-day break between surveys to reduce the impact of the observers' presence on the detection rate. We estimated the density of marmosets using Distance 7.1 (Thomas et al., 2010). This analysis fits detection functions to provide the probability of detecting groups and estimate the number of individuals potentially missed by the observers. The encounter rate (groups $/ \mathrm{km}$ ) and the mean number of individuals per group were used to estimate density.

We first used a $\chi^{2}$ test to determine the appropriate truncations and perpendicular distances intervals for adjusting the detection functions, at $\mathrm{P}>0.6$. We compared the adjustments of the detection functions using the Akaike Information Criterion (AIC). The model with the smallest AIC value was considered the best-fit for the data. If more than one function was considered a good fit (i.e. the difference in their AIC values, $\triangle \mathrm{AIC}$, was $<2$ ), we selected the model for which the density estimate had the lowest coefficient of variation. We then used the density value to estimate the abundance of $M$. marcai as $A=D^{*} a$, where $A$ is abundance, $D$ is density and $a$ is the species' geographical range.

\section{Evaluation of conservation status}

As recommended by IUCN (2012), we multiplied the lower confidence interval of the species' density by the predicted geographical area to obtain a conservative, naive estimate of population size. We calculated forest lost up to 2017 within the estimated geographical range of the species and used predictive deforestation models to assess how much of the species range will be lost by the end of 2035 (in 18 years). The IUCN criterion A assesses extinction risk over three generations, and 18 years is c. three generations for Mico leucippe (Mittermeier \& Rylands, 2008; Nishijima et al., 2012; data on generation time or lifespan for M. marcai are unavailable).

Data on the annual rate of deforestation during 20002017 were obtained from PRODES (2018). For predicted forest loss, we considered two scenarios (Soares-Filho et al., 2006): (1) governance, which assumes current deforestation trends but with a $50 \%$ cap in forest loss as a result of current laws that prohibit farmers from clearing $>50 \%$ of forest on their properties, and that existing and proposed protected areas are effectively managed, and (2) business-as-usual, which considers current deforestation trends across the Amazon basin plus the effect of infrastructure development and low effectiveness in the management of protected areas.

We calculated the amount of forest loss in each scenario and the percentage that lies within the geographical range of M. marcai, to estimate the forest loss to be expected by 2035 . We then used the IUCN Red List criteria (IUCN, 2102) to evaluate the risk of extinction.

\section{Results}

Geographical range During 2012-2014 we observed M. marcai groups in 13 localities: (1) along the left bank of the Aripuanã and Roosevelt Rivers, (2) on both banks of the Manicoré River, and (3) on both banks of the Branco River, a small tributary of the Marmelos River (Fig. 1; Table 1). Based on these observations and data from the literature, we calculated the adjusted EOO to be $31,073 \mathrm{~km}^{2}$, limited to the east by the Aripuanã River, to the west by the Marmelos River, to the north by the Madeira River and to the south by the open savannah vegetation of the Campos Amazônicos National Park, an area believed to be a distribution limit for other marmoset species (Ferrari, 1993; Garbino, 2014; Fig. 1).

Density and abundance In total we walked $271.6 \mathrm{~km}$ on the 10 transects. We observed groups of M. marcai on 30 occasions, giving an encounter rate of 0.11 individuals $/ \mathrm{km}$ (CV 21.80). The best distribution of perpendicular distances was obtained with five intervals of $10 \mathrm{~m}$ each $\left(\chi^{2}=0.52, \mathrm{df}=4, \mathrm{P}=0.91\right.$; Fig. 2$)$. The Uniform function with one cosine adjustment term provided the best fit (AIC 82.22). The number of individuals detected per group increased with perpendicular distance $(r=-0.22$; $\mathrm{P}=0.13)$ and we therefore estimated mean group size using linear regression, giving a value of 4.09 individuals/ 
TABLE 1 Occurrence records (with decimal latitude and longitude) of Mico marcai from our field surveys in the Ariupanã-Marmelos interfluve (Fig. 1) and published data.

\begin{tabular}{llll}
\hline Locality & Latitude (S) & Longitude (W) & Reference \\
\hline BR 230 (Matá Matá = Vila do Carmo) & 7.5212 & 60.6733 & This study \\
Acampamento BR 230 & 7.5348 & 60.6906 & This study \\
Igarapé do Acampamento & 7.5443 & 60.6783 & This study \\
Vicinity BR 230 & 7.4932 & 60.6868 & This study \\
Prainha, left margin of Aripuanã River & 7.2219 & 60.7316 & This study \\
Linha Nova Esperança between Branco River (right bank) and & 7.9411 & 61.6427 & This study \\
$\quad$ & & & This study \\
Santo Antônio do Matupi & 8.1049 & 61.8560 & This study \\
Manicoré River (right bank), Comunidade Mocambo & 5.9841 & 61.5374 & This study \\
Manicoré River (right bank), Comunidade Lago dos Remédios & 5.9327 & 61.4449 & This study \\
Manicoré River (left bank), Comunidade do Bom Fim & 6.0224 & 61.6492 & This study \\
Manicoré River (left bank), Comunidade Três Estrelas & 6.0221 & 61.6319 & This study \\
Manicoré River (right bank), Comunidade Terra Preta & 5.9948 & 61.5812 & van Roosmalen et al. (2000) \\
Seringal São Luis, in the vicinity of the town of Manicoré & 5.8411 & 61.3053 & This study, Alperin (2002) \\
Type locality (Rio Castanho = Roosevelt River) & 7.5500 & 60.7167 & Rohe (2007) \\
Açaí Grande Juma Development Reserve (SDR) & 6.0146 & 60.2090 & Garbino (2014) \\
Humaitá-Apuí Road (BR-230), km 292, left bank of Rio Aripuanã & 7.5333 & 60.6667 & Garbino (2014) \\
Opposite Tenharin settlement, right bank of Rio dos Marmelos (BR-230) & 7.9500 & 62.0500 &
\end{tabular}

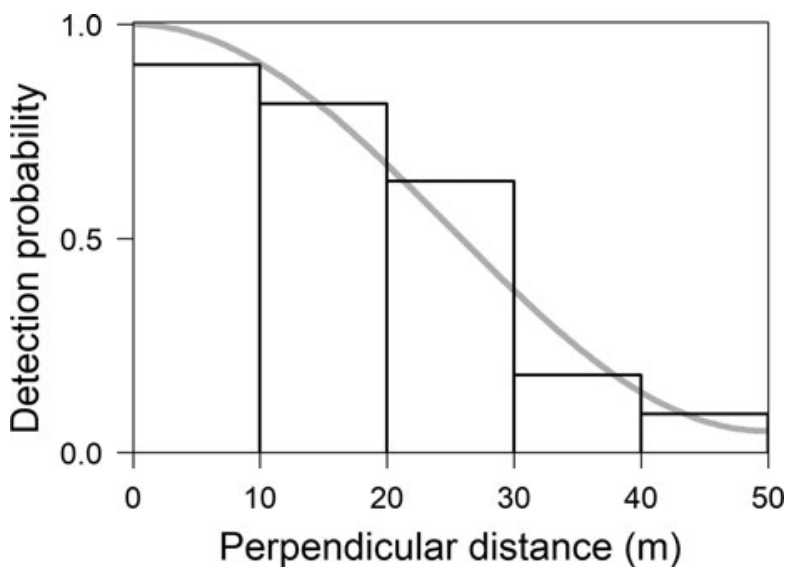

FIG. 2 Distribution of perpendicular distances of observations of M. marcai on transects in the Marmelos-Aripuanã interfluve (Fig. 1). The trend line indicates the best detection function fitted to the distance classes.

group (CI 3.23-5.16, CV 11.41, range 1-11). Density was estimated to be 8.31 individuals $/ \mathrm{km}^{2}$ (CI 4.85-14.22, CV 25.94) and group density 2.03 per $\mathrm{km}^{2}$ (CI 1.23-3.36; CV 23.29). The naive estimate of abundance within the species' range was 258,218 individuals (CI 150,705-441,860).

Conservation status Data from PRODES (2018) indicated a loss of $1,266.23 \mathrm{~km}^{2}$ of forest cover up to 2017 ( $4 \%$ of the species' estimated geographical range), and spatial predictive models (Soares-Filho et al., 2006) indicate that $5,800 \mathrm{~km}^{2}$ (19\%) of forest will be lost in the next 18 years under the governance scenario, and $10,396 \mathrm{~km}^{2}$ (33\%) under the business-as-usual scenario (Fig. 3). Using our conservative estimate of population size (150,705 individuals), these levels of forest loss extrapolate to a loss of $13,430 \mathrm{M}$. marcai under the governance and 49,733 under the business-as-usual scenarios by 2035 . This indicates that, according to the business-as-usual scenario, the species should be categorized as Vulnerable based on criteria A3cd (an estimated 30\% population reduction projected over the next 18 years, c. three generations), as a result of a predicted decline in EOO.

\section{Discussion}

IUCN Red List guidelines (IUCN, 2012) recommend that species should be assessed using all available evidence to avoid, if possible, placing a species in the Data Deficient category (IUCN 2012). This category does not mean a species is without threats, but rather that it is a priority for research, and there are examples of Data Deficient species being categorized as threatened once relevant data became available (Bland et al., 2015). This is also the case for M. marcai, which we recommend should be categorized as Vulnerable.

Our analysis indicates that $M$. marcai has an estimated minimum population of 150,705 individuals in a geographical range of $31,073 \mathrm{~km}^{2}$. Variation in group size may bias density estimates but the coefficient of variation of the group size for Mico marcai is $11.41 \%$ with a confidence interval of $3-5$, which is lower than estimated group sizes of other Neotropical primate species (i.e. those in the genera Saimiri and Sapajus; Peres 1993). Furthermore, despite employing distance sampling in only two regions within the species' EOO, we surveyed the predominant forest type (dense 

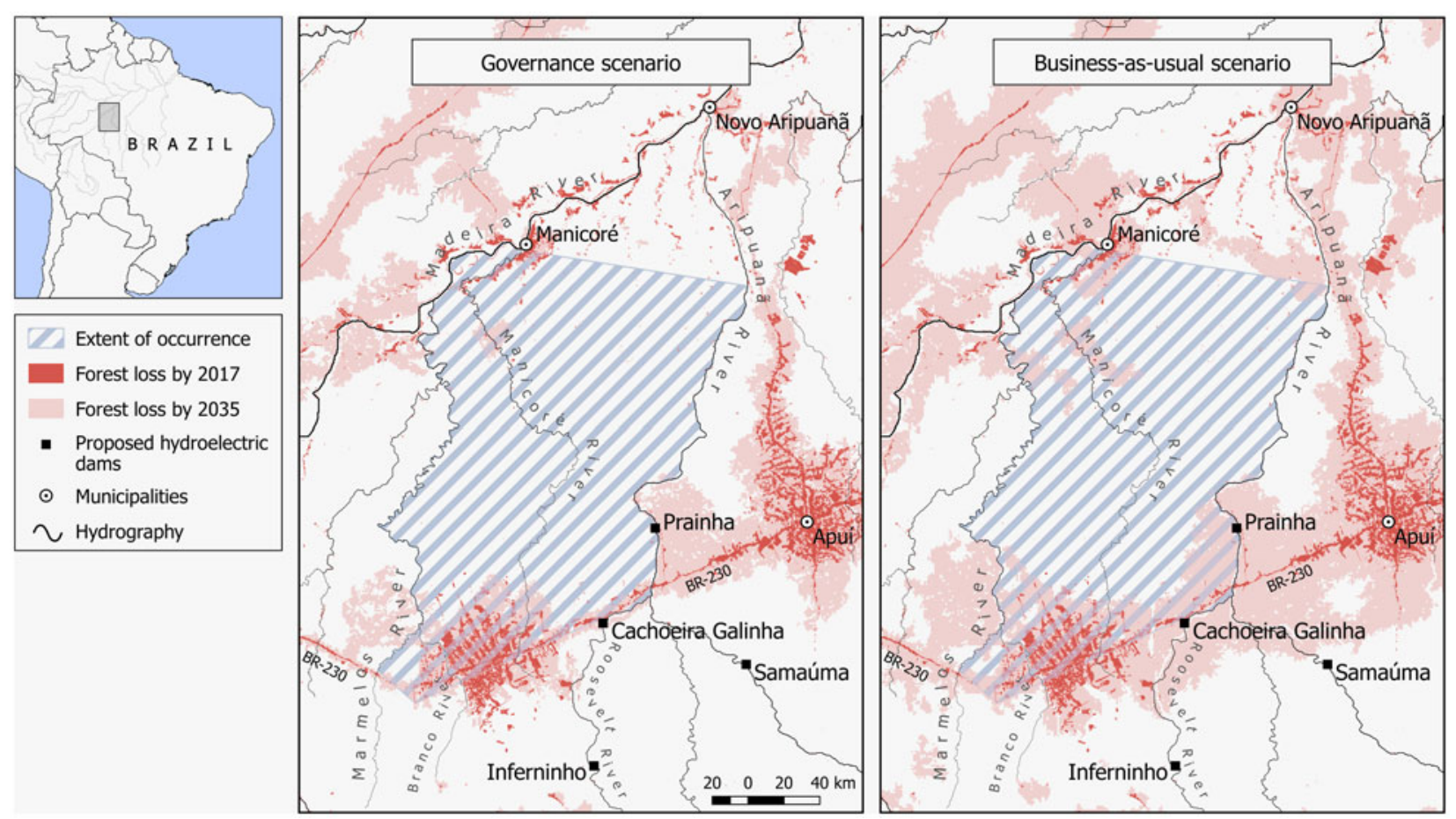

FIG. 3 Extent of occurrence of M. marcai in the Aripuanã-Marmelos interfluve (Fig. 1), accumulated forest loss from 2000 to 2017 (PRODES, 2018), and forest loss predicted by 2035 under governance and business-as-usual scenarios (see text for details).

lowland rainforest) within the species' range rather than the few patches of open lowland rainforest and pioneer vegetation.

Despite a relatively large estimated population, the high rate of deforestation in this region, caused by the everexpanding Brazilian agriculture frontier and infrastructure development (roads and hydroelectric power plants), poses a grave threat to the survival of $M$. marcai and other marmoset species. A projected loss of $33 \%$ of the species total range by 2035 under a business-as-usual scenario is a bleak outlook.

Although part of the current geographical range of $M$. marcai is theoretically conserved by Indigenous Lands and protected areas, these units are under pressure from the current trend of protected area downgrading, downsizing, and degazettement in the Brazilian Amazon (Bernard et al., 2014; Ferreira et al., 2014; Pack et al., 2016). Three main factors drive this, decreasing the effectiveness of protected areas within $M$. marcai's range: (1) political instability and changes in governmental policies on land use and conservation in the Amazon, (2) planned hydroelectric dams, especially on the southern tributaries of the Amazon River, and (3) increases in human settlements surrounding the Indigenous Lands and protected areas. Four hydroelectric dams will be constructed within $M$. marcai's range, flooding an area of $1,118.42 \mathrm{~km}^{2}$ (ANEEL, 2012). The planned dams and reservoirs of Prainha and Samaúma on the Aripuanã River, and the reservoirs Inferninho and Cachoeira Galinha on the Roosevelt River, will reduce the area of occurrence of $M$. marcai and two other marmosets: the sympatric Callibella humilis and the marmoset found along the right bank of Aripuanã River, Mico chrysoleucos (Silva et al., 2018a,b). In addition, the TransAmazonian Highway, which has negatively affected the conservation of southern Amazonia (Kirby et al., 2006; Carrero \& Fearnside, 2011), bisects the range of M. marcai, and the municipalities of Apuí and Manicoré lie in the arc of cattle ranching.

In 2013 the Brazilian government, through the Chico Mendes Institute for Biodiversity Conservation, assessed the conservation status of Brazilian primates (ICMBio, 2018), in which nine Mico species were categorized as Least Concern, two as Near Threatened, and one as Vulnerable, with only $M$. marcai categorized as Data Deficient. However, the threats to Amazonian marmosets have been documented in only a few studies (Gonçalves et al., 2003; Ochoa-Quintero et al., 2017) and the range of many of these species has been estimated from relatively few records (Ferrari, 1993; Silva Jr \& Noronha, 1995; van Roosmalen et al., 2000; Noronha et al. 2007; Fialho, 2010; Garbino, 2011). Most Mico species inhabit the arc of deforestation, where forest loss and other threats are similar to or higher than those estimated here for M. marcai. For example, Ochoa-Quintero et al. (2017) predicted a decline of $>50 \%$ of the potential distribution of $M$. rondo$n i$ by 2030 as a result of forest loss, which meets the IUCN criteria for Endangered $\left(A_{3}\right)$. As a follow-up of our fieldwork and data analysis, we have passed our results and 
recommendations to the Red List Authority. We advocate that the conservation status of all Amazonian marmosets should be re-examined following the methods we have used for M. marcai.

Acknowledgements Data collection and analysis were supported by International Association for Conscientiology Expansion, Mamirauá Institute for Sustainable Development, Conselho Nacional de Desenvolvimento Científico e Tecnológico (CNPq 200502/2015-8), Conservation Leadership Programme, Conservation International, Primate Conservation Inc., International Primatological Society, and Idea Wild. We thank the Gordon and Betty Moore Foundation (Grant Agreement for Instituto de Desenvolvimento Sustentável Mamirauá, \#5344), Isaac Theobald and Aldeísa for logistical support, and Catitu and José's family for support in the field.

Author contributions Study design: FES, HEB, JRG, LPL, RCA, IJL, CLBF, AST and MIS; data collection: FES, JRG, LPL, RCA, IJL, ATS and MIS; data analysis: FES, HEB, JRG, CLBF and JPB; all authors contributed to interpretation of results and writing.

\section{Conflicts of interest None.}

Ethical standards This research adhered to Brazilian law governing primate research and the principles of he American Society of Primatologists for the ethical treatment of primates. Research permits were granted by ICMBio/SISBio (number 44707-2).

\section{References}

Alperin, R. (1993) Callithrix argentata (Linnaeus, 1771): considerações taxonômicas e descrição de subespécie nova. Boletim do Museu Paraense Emílio Goeldi, Série Zoologia, 9, 317-328.

Alperin, R. (2002) Sobre a localidade tipo de Mico marcai (Alperin, 1993). Neotropical Primates, 10, 126-128.

Anderson, A.B. (1981) White-Sand vegetation of Brazilian Amazonia. Biotropica, 13, 199-210.

Aneel (Agéncia Nacional de Energia Elétrica) (2012) Despacho $n^{o}$ 1.971, de 12 de Junho de 2012. http://www.aneel.gov.br/ inventario-hidreletricos [accessed 13 July 2015].

Ayres, J.M., de Malghaes Lima, D., Martins, E.S. \& Barreiros, J.K.L. (1991) On the track of the road: changes in subsistence hunting in a Brazilian Amazonian village. In Neotropical Wildlife Use and Conservation (eds J.G. Robinson \& K.H. Redford), pp. 82-92. The University of Chicago Press, Chicago, USA.

Bernard, E., Penna, L.A.O. \& Araújo, E. (2014) Downgrading, downsizing, degazettement, and reclassification of protected areas in Brazil. Conservation Biology, 28, 939-950.

Bland, L.M., Collen, B., Orme, C.D.L. \& Bielby, J. (2015) Predicting the conservation status of data-deficient species. Conservation Biology, 29, 250-259.

Buckland, S.T., Anderson, D.R., Burnham, K.P. \& LaAke, J.L. (1993) Distance Sampling: Estimating Abundance of Biological Populations. Chapman and Hall, New York, USA.

Carrero, G.C., Albuja, G., Frizo, P., Hoffman, E.K., Alves, C. \& Bezerra, C.D.S. (2015) A Cadeia Produtiva da Carne Bovina no Amazonas. Instituto de Conservaçã e Desenvolvimento Sustentável da Amazônia, Manaus, Brazil.

Carrero, G.C. \& Fearnside, P.M. (2011) Forest clearing dynamics and the expansion of landholdings in Apuí, a deforestation hotspot on Brazil's Transamazon highway. Ecology and Society, 16, 26.

Fearnside, P.M., de Graca, P.M.L.A., Keizer, E.W.H., Maldonado, F.D., Barbosa, R.I. \& Nogueira, E.M. (2009)
Modelagem de desmatamento e emissões de gases de efeito estufa na região sob influência da rodovia Manaus-Porto Velho (BR-319). Revista Brasileira de Meteorologia, 24, 208-233.

Ferrari, S. (1993) Update of Callithrix nigriceps distribution. Neotropical Primates, 1, 11-13.

Ferreira, J., Aragao, L.E.O.C., Barlow, J., Barreto, P., Berenguer, E., Bustamante, M. et al. (2014) Brazil's environmental leadership at risk. Science, 346, 706-707.

FIALho, M.D.S. (2010) Contribuição à distribuição do gênero Mico, (Callitrichidae, Primates) no médio Teles Pires, Jacareacanga, Pará. Neotropical Primates, 17, 21-22.

Garbino, G.S.T. (2011) The southernmost record of Mico emiliae (Thomas, 1920) for the state of Mato Grosso, northern Brazil. Neotropical Primates, 18, 53-55.

Garbino, G.S.T. (2014) The taxonomic status of Mico marcai (Alperin 1993) and Mico manicorensis (van Roosmalen et al., 200o) (Cebidae, Callitrichinae) from Southwestern Brazilian Amazonia. International Journal of Primatology, 35, 529-546.

Gonçalves, E.C., Ferrari, S.F., Silva, A.L., Coutinho, P.E.G., Menezes, E.V. \& Schneider, M.P. (2003) Effects of habitat fragmentation on the genetic variability of silvery marmosets, Mico argentatus. In Primates in Fragments: Ecology and Conservation (ed L.K. Marsh), pp. 17-28. Kluwer Academic Publishers, New York, USA.

Hayakawa, E.H. \& RossetTi, D.F. (2015) Late Quaternary dynamics in the Madeira river basin, southern Amazonia (Brazil), as revealed by paleomorphological analysis. Anais da Academia Brasileira de Ciências, 87, 29-49.

ICMBIO (2018) Fauna Brasileira. Http://www.icmbio.gov.br/portal/ faunabrasileira [accessed 20 November 2017].

IUCN (2012) IUCN red list categories and criteria. Version 3.1 2nd edition. IUCN, Gland, Switzerland, and Cambridge, UK.

Kirby, K., Laurance, W., Albernaz, A., Schroth, G., Fearnside, P., Bergen, S. et al. (2006) The future of deforestation in the Brazilian Amazon. Futures, 38, 432-453.

Mittermeier, R.A. \& Rylands, A.B. (2008) Mico leucippe. The IUCN Red List of Threatened Species 2008. Http://dx.doi.org/10.2305/IUCN. UK.2008.RLTS.T39912A10283351.en [accessed 4 October 2018].

Nepstad, D., Carvalho, G., Cristina, A., Alencar, A., Paulo, Ä., Bishop, J. et al. (2001) Road paving, fire regime feedbacks, and the future of Amazon forests. Forest Ecology and Management, 154, 395-407.

Nishijima, K., Saitoh, R., Tanaka, S., Ohsato-Suzuki, M., Ohno, T. \& KitAjima, S. (2012). Life span of common marmoset (Callithrix jacchus) at CLEA Japan breeding colony. Biogerontology, 13, 439-443.

Noronha, M.A., Spironello, W.R. \& Ferreira, D.C. (2007). New occurrence records of Mico acariensis (Primates, Callitrichidae). Neotropical Primates, 14, 140.

Ochoa-Quintero, J., Chang, C., Gardner, T., Rezende Messias, M., Sutherland, W. \& Delben, F. (2017) Habitat loss on Rondon's marmoset potential distribution. Land, 6, 8 .

Pack, S.M., Ferreira, M.N., Krithivasan, R., Murrow, J., Bernard, E. \& Mascia, M.B. (2016) Protected area downgrading, downsizing, and degazettement (PADDD) in the Amazon. Biological Conservation, 197, 32-39.

Peres, C.A. (1993) Structure and spatial organization of an Amazonian terra firme forest primate community. Journal of Tropical Ecology, 9, 259-276.

PRODES (2018) PRODES. Http://www.dpi.inpe.br/prodesdigital/ prodes.php [accessed 24 June 2018].

RöHE, F. (2007) Mamíferos de médio e grande porte. In Biodiversidade do Médio Madeira: Bases Científicas Para Propostas de Conservação (eds L.R. Py-Daniel, C.P. Deus, A.L. Henriques, D.M. Pimpão \& O.M. Ribeiro), pp. 195-209. Instituto Nacional de Pesquisas da Amazônia, Manaus, Brazil. 
Rylands, A.B., Schneider, H., Langguth, A., Mittermeier, R.A., Groves, C.P. \& Rodríguez-LunA, E. (2000) An assessment of the diversity of new world primates. Neotropical Primates, 8, 61-93.

Rylands, A.B. \& Silva, JR, J.S. (2008) Mico marcai. In The IUCN Red List of Threatened Species 2008. Http://dx.doi.org/10.2305/IUCN. UK.2008.RLTS.T39914A10284223.en [accessed 21 November 2017].

Silva, JR, J.S. \& Noronha, M.A. (1995) A new record for Callithrix mauesi Mittermeier, Schwarz and Ayres, 1992. Neotropical Primates, 3, 79-81.

Silva, F.E., Costa-Araújo, R., Boubli, J.P., Santana, M.I., Franco, C.L.B., Bertuol, F. et al. (2018a) In Search of a meaningful classification for Amazonian marmosets: should dwarf marmosets be considered Mico congenerics? Zoologica Scripta, 47, 133-143.

Silva, F.E., Endo, W., de Sousa e Silva Júnior, J., Marcelo, J. \& Santos, A. (2018b) New insights into the distribution and conservation status of the golden-white tassel-ear marmoset Mico chrysoleucos (Primates, Callitrichidae). Primates, 59, 347-353.
Silva, F.E., Nunes, H.G. \& Bastos, A. (2013) Rediscovery of Marca's marmoset and the challenges for its conservation. Oryx, 47, 327.

Soares-Filho, B.S., Nepstad, D.C., Curran, L.M., Cerqueira, G. C., GARCiA, R.A., Ramos, C.A. et al. (2006) Modelling conservation in the Amazon basin. Nature, 440, 520-523.

Thomas, L., Buckland, S.T., Rexstad, E.A., LaAke, J.L., Strindberg, S., Hedley, S.L. et al. (2010) Distance software: design and analysis of distance sampling surveys for estimating population size. Journal of Applied Ecology, 47, 5-14.

Van Roosmalen, M.G.M., Van Roosmalen, T., Mittermeier, R. A. \& Rylands, A.B. (2000) Two new species of marmoset, genus Callithrix Erxleben, 1777 (Callithrichidae, Primates), from the Tapajós/Madeira interfluvium, South Central Amazonia, Brazil. Neotropical Primates, 8, 2-18.

Vieira, I.C.G., Toledo, P.M., Silva, J.M.C. \& Higuchi, H. (2008) Deforestation and threats to the biodiversity of Amazonia. Brazilian Journal of Biology, 68, 949-956. 